\title{
The Effect of Students' Academic Majors on Practice of E-Shopping of Clothing
}

\author{
Maha Abdullah Al Dabbagh, Amal Othman Al-Amoudi, Tahani Abdullah Abdul-Baqi Ijaz Elias, \\ Kholoud Issa, Shurooq Abdul Mohsen Al-Jayed, Lojain Al Hababi
}

King Abdulaziz University, Jeddah, KSA

Email: Maldabag@kau.edu.sa,AOMARALFAKIHALALAMOODI@stu.kau.edu.sa, telias@stu.kau.edu.sa, keishaque@stu.kau.edu.sa, shusseinalged@stu.kau.edu.sa,ImaIhababi@stu.kau.edu.sa

How to cite this paper: Al Dabbagh, M. A., Al-Amoudi, A. O., Abdul-Baqi Ijaz Elias, T. A., Issa, K., Al-Jayed, S. A. M., \& Al Hababi, L. (2021). The Effect of Students' Academic Majors on Practice of E-Shopping of Clothing. Open Journal of Social Sciences, 9, 119-132.

https://doi.org/10.4236/jss.2021.96011

Received: May 30, 2021

Accepted: June 13, 2021

Published: June 16, 2021

Copyright $\odot 2021$ by author(s) and Scientific Research Publishing Inc. This work is licensed under the Creative Commons Attribution International License (CC BY 4.0).

http://creativecommons.org/licenses/by/4.0/

\begin{abstract}
Identifying good clothes needs knowledge and experience, and the academic major plays an important role when it comes to selection of clothes. This research aims to examine the effect of difference in students' academic majors on practice of e-shopping of clothes. The study has applied the experimental approach using a questionnaire comprised of 27 questions targeting (200) students from various academic majors. The data were analyzed using the (SPSS) program. To verify the hypotheses of the study, the Chi Square Test was used at a level of statistical significance (0.05) to ensure that the difference in the students' academic major may affect the study variables. It was found that there are statistically significant differences at a significant level (0.05) in favor of female students from Fashion and Textiles major in terms of feasibility of e-shopping over other majors. Fashion and Textiles students were found to be more interested in examining the raw materials of clothes and accuracy and cleanliness of knitted clothes; they rarely return clothes after purchasing, can determine the best choice for body style from among similar designs compared to female students of other academic majors, and finally they can make adjustments to the clothes after purchasing it, and add some aesthetic touches to increase its value of appearance compared to female students of other academic majors.
\end{abstract}

\section{Keywords}

E-Shopping, Academic Major, Female University Students

\section{Introduction}

Technological development in means of communication has facilitated the pursuit of all desires and needs quickly and easily and with multiple options. The 
information revolution that the world is witnessing has resulted in a digital economy, based on electronic commerce and information technology that affected various economic activities. The indicator of a number of internet users indirectly reflects the reality of e-commerce (Shaheen, 2017) and e-shopping is considered one of the e-commerce practices.

The Kingdom's Vision 2030 aims to create a viable society with a prosperous economy, an ambitious nation, and a tremendous industrial development to provide the basics of life for citizens, residents and visitors easily and smoothly (Saudi Vision 2030). It promoted e-commerce with multiple options (Soleimani, 2018), an increased population's level of income, development of infrastructure, encouraged a strong growth of the e-commerce industry, and facilitated spread of the Internet (Al-Khail \& Saleh, 2020).

The fashion sector in the Kingdom of Saudi Arabia has been linked to structural changes in educational institutions, and therefore, the field was transformed from educational specialization to artistic and creative one, with around 11 Saudi universities offering programs specialized in fashion, more than 900 Saudi men and women being employed in professions in the fashion sector. Thus, we may find that fashion sector is largely confined to the consumption framework, as a Saudi individual may spend (4\%) of his monthly income on consuming fabrics, shoes and clothes (Ministry of Culture, 2019). With the introduction of the Internet, commercial and social changes occurred (Abdul-Ghani, 2005) especially in the consumption behavior of buying and preferring different commodities. Therefore, awareness and consumption are related and affected by the educational process of individuals.

Learning behavior affects and is affected by the process of consuming clothes, because the needs and requirements of consumers are constantly changing or affected by various economic, social and psychological factors (Al-Dabbagh, 2009), and the important role of clothing in people's appearance requires a careful selection of clothes (Farghali, 2012). So, electronic shopping options for clothes are varied, and it is the consumer who makes his choice. Selecting clothes needs knowledge and experience, and the academic major plays an important role when it comes to selection of clothes, and as Saudi consumers enjoy easy and free educational opportunities most of the time, studying the impact of academic major will have clear results, especially those related to electronic shopping of clothes.

\section{Problem of the Study}

In view of recent advancements in science and technology of electronic marketing that saved time and effort spent in traditional stores, especially clothes outlets, and since consumers practice electronic shopping, it is logical that studies should pay attention to the stereotypes followed in consumer behavior and the factors affecting his purchasing decisions. Although some studies have dealt with such issues, a few studies have dealt with the impact of students' academic major 
on e-purchase of clothes. Therefore, this research will examine the effect of difference in students' academic majors on options of e-shopping of clothes.

\section{The study raises its problem through the following questions:}

- Does the difference in academic majors of female students affect practice of e-shopping of clothes?

- Is the level of interest in the type of raw materials of clothes and accuracy and cleanliness of knitting higher among female students of the Fashion and Textile major?

- Does the number of returns of clothes differ between female students of the Fashion and Textile major and female students of other academic majors?

- Can female students of the Fashion and Textile major determine the best choice for body style from among similar designs?

- Do students of the Fashion and Textile major have the desire to make adjustments to the clothes after purchasing it, and add some aesthetic touches to increase its value of appearance?

\section{Study Objectives}

- To identify if the difference in academic majors of female students affects practice of e-shopping of clothes.

- To identify if the level of interest in the type of raw materials of clothes and accuracy and cleanliness of knitting higher among female students of the Fashion and Textile major.

- To identify whether or not the number of returns of clothes differ between female students of the Fashion and Textile major and female students of other academic majors.

- To ascertain that female students of the Fashion and Textile major can determine the best choice for body style from among similar designs?

- To identify whether Fashion and Textile major have the desire to make adjustments to the clothes after purchasing it, and add some aesthetic touches to increase its value of appearance.

This study aims to identify the effect of differences of academic majors of female students on options of e-shopping of clothes.

\section{Study Significance}

- Raise the level of social awareness by identifying the impact of academic majors on consumer purchasing behaviors.

- Support consumer protection societies with information on the impact of academic majors on consumer behavior.

- Enrich the scientific library with researches that study the impact of students' academic majors on options of e-shopping of clothes.

\section{Literature Review}

Many studies have dealt with the subject matter of current study from different angles. In the following lines, a review of several literatures dealing with Elec- 
tronic Shopping, selection of clothing, consumer awareness and academic majors is presented to have an in-depth overview of the focus of current study.

In terms of practice of Electronic Shopping, Kuswanto et al. (2019), investigated the factors influencing university students' online shopping behavior in Surabaya as one of the fastest growing cities in Indonesia, an important issue that has never been explored. The analysis shows that the students' online shopping behavior is significantly influenced by enjoyment, perceived risk, and social influence. Kuswanto's study agreed with the current study in terms of type of sample but differed in that it did not address the relation between clothing and academic majors.

Lee \& Lee (2019) examined the relationship between online retail therapy and consumers' attitudes towards online fashion shopping malls (ATO) based on the stimulus-organism-response model. The results indicated that aesthetics has a significant and direct effect on ATO. However, model attractiveness has an indirect effect on ATO through PMR and NMR. In addition, the direct effect of aesthetics on ATO is greater than the indirect effect of model attractiveness. Therefore, online fashion shopping malls need to concentrate on improving the aesthetics of the shopping malls. For fashion shopping malls that do not have the capacity to improve the aesthetics, it is possible to improve ATO by using highly attractive models. The study tackled the subject of current study but differed in the objective.

Ofori \& Appiah-Nimo (2019) sought to identify the determinants of online shopping behaviour among tertiary students through the lens of the Technology Acceptance Model (TAM). The study proposed a revised TAM that integrated perceived cost and perceived risk to investigate what determined students online shopping intention and actual use. The survey involved a sample of 580 undergraduate students. The results showed that effect of ease of use on usefulness was very significant as same has been predicted by the Technology Acceptance Model. It also recommends future studies to employ additional determining factors such as the type of product/service, convenience and personal/demographic and geographic factors as influential to students' online purchasing behavior. The study agreed with the current study in terms of sampling but differed in the objective.

Ghalawat et al. (2018) examined the factors affecting customer satisfaction towards online shopping among university students. Questionnaires were distributed among university student to gauge their factors to shop online. Based on the research, the product quality, brand and shopping experience have a significant relationship to customer satisfaction towards online shopping among university students at UTeM. The study agreed with the current study in terms of sampling but differed in the objective as well as in the geographical limit.

Balasudarsun (2017) dealt with the impact of social factors such as family, friends, their reviews, and external and interpersonal factors on planned and unplanned online purchases. This descriptive study was conducted using struc- 
tured survey questionnaires. This study establishes that Indian, Singaporean, and Malaysian students are careful and think twice before making purchases, keep shopping lists, are particular about e-stores, and will not purchase without a plan. However, in Uzbekistan and parts of Singapore, unplanned purchases happen often due to patterns of increased spending and impulsive purchases. Since the internet and e-stores are especially new in Uzbekistan, its youth are tempted to browse online suggestions and impulsively act on reviews from friends or peers. The study differs with the current one in that it studied electronic shopping as per different geographical limits, but did not study a specific commodity not it examined the effect of academic majors on purchasing behavior.

As for the selection of clothing, Li \& Nakayama (2019) focused on the college students' online purchase of clothing, and compared the consumption behaviors of Japanese and Chinese college students to explore the characteristics of Japanese and Chinese college students' consumption behaviors. After summarizing the theoretical research in the past, based on the online sales of clothing, we conducted a questionnaire survey among college students in Japan and China from the perspective of Marketing Mix. The results show that when the college students in Japan and China purchase clothing, there was a big difference in CD purchase channel, $\mathrm{CD}$ commodity price, $\mathrm{CD}$ commodity quality and CD network comments. The study agreed with the current study in terms of sampling but differed in terms of spatial and objective limits.

Sethi et al.'s (2018) identified the factors effecting purchases intention of Millennial on an online fashion store. The objectives of the research were to investigate the relationship between purchase intention of Millennials and their attitude towards word of mouth and product variety available on online fashion apparels shopping sites. Descriptive research was considered and a mailing survey was conducted with 298 millennials who had an access to the Internet in Delhi NCR. The study discloses that product variety and online reviews are two factors which significantly influence the shaping of online purchase intention especially in the case of online fashion stores.

In terms of impact of academic majors on consumer behavior, Salem and Al-Marsoumi's (2020) aimed to identify the level of religious values among students of the Almaarif University College and their relations to some variables such as academic majors, academic stage, and gender. The research sample consisted of (202) male and female students distributed among the college departments according to their majors. The researcher used the questionnaire consisting of (5) questions. After authenticating its validity and consistency, several results were obtained as follows: the level of religious values among students was high and of significance. This was attributed to the social environment in the family, school and society which adhere to religious values, and that the academic subjects studied by students in the previous and current stages have an impact on those values, as the study revealed a difference in the level of religious 
values between students according to their majors. The results have shown that there is a relationship between the academic stage and the level of values in favor of undergraduate students (last year).

As for consumer awareness, Kautish \& Sharma (2018) examined the underlying relationships among two distinct forms of consumer values, namely, instrumental and terminal values, fashion consciousness and behavioral intentions in the context of online fashion apparel retail sector. A conceptual model and subsequent measurement scale were developed, grounded on in-depth review of the extensive literature and validated with customers engaged in online shopping of fashion apparels. The model was empirically examined, and a total of 395 responses were gathered from an online survey administered at a northeastern university in India. The model was validated using structural equation modelling, and a two-step approach suggested by Anderson and Gerbing (1988) was used to evaluate the measurement and structural models for the research. The results of the study indicate that instrumental and terminal values significantly affect fashion consciousness, and fashion consciousness has a significant impact on behavioral intentions as well. The research brings out that fashion consciousness acts as a partial mediator between instrumental/terminal values and behavioral intentions. It is noteworthy that compared to terminal values instrumental values display a greater influence on both the variables fashion consciousness and behavioral intentions.

The study agreed with the current study in that it studies electronic shopping for clothes and differed in not addressing the impact of academic majors on behavioral intentions.

\section{Study Hypothesis}

- First hypothesis: There are statistically significant differences at a significant level (0.05) between levels of practicing e-shopping of clothes among female students as per respective academic majors in favor of female students from Fashion and Textiles major.

- Second hypothesis: There are statistically significant differences at a significant level (0.05) among female university students in terms of degree of interest in examining the raw materials of clothes and accuracy and cleanliness of knitted clothes, in favor of female students from Fashion and Textiles major.

- Third hypothesis: There is a difference in the number of returned clothes between female students of other academic majors and students of Fashion and Textile dept.

- Fourth hypothesis: Students of Fashion and Textile major can determine the ideal choice for body style from among similar clothing designs.

- Fifth hypothesis: Students of Fashion and Textile major are distinguished in their ability to make adjustments to the clothes after purchasing it and add some aesthetic touches to increase its value of appearance. 


\section{Methodology of Study}

This research follows the experimental approach for its relevance to the subject of the study, as the experimental approach relies on practical experience as a means of obtaining data and information about the phenomenon or studied event.

The experimental approach was applied by making questionnaires targeting students from various academic majors, then all data were analyzed, discussed and later the results were extracted.

\section{The Study Tools}

An electronic questionnaire comprised of 27 questions to show results that achieve the goal of the study, and 6 questions for demographic data.

\section{Limits of Analysis Tools}

- Objective limits: The effect of academic majors on electronic purchase of clothing.

- Human limits: University student consumers.

- Spatial limits: The universities of the Kingdom of Saudi Arabia in the Makkah region.

- Temporal limits: The end of the first semester 1442 AH Rabi 'al-Thani, corresponding to November, 2020.

\section{Data Analysis and Discussion of Results}

After presenting the study's theoretical framework which established the basis of the study problem through its chapters, the practical side of the study was introduced in the form of the procedures applied by the researcher, starting from the pilot study, the method and tools used in the research, the fields of research, the sample and the way it was selected, to the statistical methods used to process the data. After completing the data collection process, data were analyzed by the (SPSS) program. The results of the study were as follows:

\subsection{Characteristics of Study Sample}

As shown in Figure 1, the university majors were divided into Major of Fashion, Textile and Design, and other majors, as per the study's hypotheses. The percentage of sample specialized in Fashion, Textile and Design was (45\%) compared to $(55 \%)$ of other majors.

As shown in Table 1, it is evident that $45 \%$ of the sample are of the age group (18 - 24 years), $21 \%$ of the age group ( 25 - 31 years), 14\% of the age group (32 38 years), $14 \%$ of the age group (39- 45 years), and 13\% of age group (over 46 years). With regard to the universities to which members of the sample are affiliated, a majority of the sample were from King Abdul Aziz University (41\%), followed by Umm Al-Qura University (16\%), then Jeddah University (8\%), King Saud University (4\%) and Tabuk University (4\%) and finally other universities 


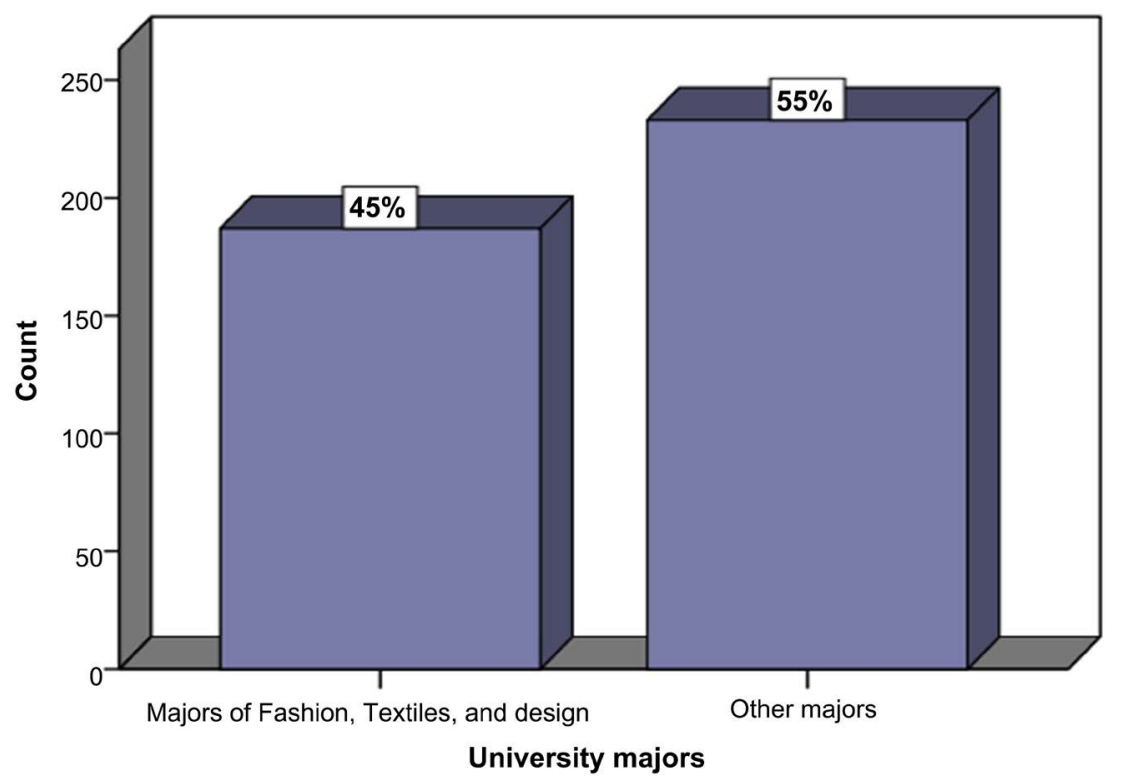

Figure 1. Percentage of students of fashion, textiles, and design versus other majors.

Table 1. Characteristics of sample.

\begin{tabular}{|c|c|c|c|}
\hline Property & Category & Number & Ratio \\
\hline \multirow{5}{*}{ Age categories } & $18-24$ years old & 187 & $45 \%$ \\
\hline & 25 - 31 years old & 98 & $21 \%$ \\
\hline & $32-38$ years old & 57 & $14 \%$ \\
\hline & $39-45$ years old & 30 & $7 \%$ \\
\hline & 46 years and over & 53 & $13 \%$ \\
\hline \multirow{6}{*}{ Name of University } & King Abdulaziz University & 172 & $41 \%$ \\
\hline & Umm Al Qura University & 66 & $16 \%$ \\
\hline & Jeddah University College & 35 & $8 \%$ \\
\hline & King Saud University & 18 & $4 \%$ \\
\hline & Tabouk university & 30 & $7 \%$ \\
\hline & Other universities and colleges & 99 & $24 \%$ \\
\hline \multirow{3}{*}{ Educational level } & Bachelor & 317 & $75 \%$ \\
\hline & M.A. & 62 & $15 \%$ \\
\hline & $\mathrm{PhD}$ & 41 & $10 \%$ \\
\hline \multirow{4}{*}{ Monthly income in riyals } & Less than 2000 riyals & 200 & $48 \%$ \\
\hline & 2000 - 6000 riyals & 86 & $20 \%$ \\
\hline & $6001-10,000$ riyals & 53 & $13 \%$ \\
\hline & More than 10,000 riyals & 81 & $19 \%$ \\
\hline
\end{tabular}

and colleges (24\%). Bachelor's students formed the majority of the sample (75\%), followed by Master students (15\%) and $\mathrm{PhDs}$ candidates (10\%). As for the monthly income, (48\%) of sample had a monthly income (less than 2000 riy- 
als), (20\%) had an income ranging between (2000 - 6000 riyals), (13\%) between (6000 - 10,000 riyals), and finally (19\%) had a monthly income of more than (10,000 riyals).

\subsection{Testing the Hypotheses of the Study}

To verify the hypotheses of the study, the Chi Square Test was used at a level of statistical significance (0.05) to ensure that the difference in the students 'academic major may affect the study variables. The results of the tests are as shown below:

First hypothesis: There are statistically significant differences at a significant level (0.05) between levels of practicing e-shopping of clothes among female students as per respective academic majors in favor of female students from Fashion and Textiles major.

It is evident from Table 2 that there were statistically significant differences attributed to academic major with regard to the number of hours students spend on the Internet per day $(P$-value $<0.05)$, as students of Textile and Design major spend more time on the Internet than students of other majors. Meanwhile, there were no statistically significant differences attributed to the academic major with regard to other variables related to online shopping for clothes, the number of e-purchasing of clothing, planning for e-shopping, viewing clothes on websites, and searching for raw materials on websites.

Second hypothesis: There are statistically significant differences at a significant level (0.05) among female university students in terms of degree of interest in examining the raw materials of clothes and accuracy and cleanliness of knitted clothes, in favor of female students from Fashion and Textiles major.

It is evident from Table 3 that there were statistically significant differences attributed to the academic majors with regard to students' ability to differentiate between displayed clothes with regards to their conformity with modern fashion trends ( $P$-value $<0.05)$, as students of Textile and Design major were able to differentiate between displayed clothes and their conformity with modern fashion

Table 2. The relation between levels of practicing e-shopping of clothes among female students as per respective academic majors.

\begin{tabular}{lcc}
\hline \multicolumn{1}{c}{ Study variable } & Chi-Square VALUE & $P$-value \\
\hline How many hours do you spend on the internet per day & $\mathbf{1 5 . 8 2}$ & $\mathbf{0 . 0 1 1}$ \\
I do prefer online shopping to buy clothes than traditional shopping. & 4.41 & 0.110 \\
The approximate number of online purchases of clothes during the & 5.63 & 0.131 \\
year. & 1.99 & 0.547 \\
$\begin{array}{l}\text { I usually plan before I buy clothes through online shopping } \\
\text { The preferred option for viewing clothes on internet sites (you can } \\
\text { choose more than one paragraph) }\end{array}$ & 11.27 & 0.127 \\
$\begin{array}{l}\text { Keen to research the type of materials used in a model before } \\
\text { adding it to the cart }\end{array}$ & 1.64 & 0.442 \\
\hline
\end{tabular}


Table 3. The level of female university students' interest in examining clothes' raw materials and accuracy and cleanliness of knitted clothes, was in favor of female students from Fashion and Textiles dept.

\begin{tabular}{llc}
\hline \multicolumn{1}{c}{ Study variable } & Chi-Square VALUE & $P$-value \\
\hline $\begin{array}{l}\text { I have an interest to zoom in on the model's image to see the details } \\
\text { of clothes' raw materials. }\end{array}$ & 2.30 & 0.316 \\
$\begin{array}{l}\text { I zoom in to the finest details of the model to see the cleanliness of } \\
\text { its stitching. }\end{array}$ & 2.59 & 0.274 \\
$\begin{array}{l}\text { I can distinguish between displayed clothes in terms of their } \\
\text { conformity with modern fashion trends. }\end{array}$ & $\mathbf{1 2 . 8 7}$ & $\mathbf{0 . 0 0 2}$ \\
$\begin{array}{l}\text { I pay more attention to modern designs when choosing clothes } \\
\text { than to raw materials. }\end{array}$ & 0.10 & 0.950 \\
$\begin{array}{l}\text { I care more about the price than the raw materials. } \\
\text { I care more about price than designs. }\end{array}$ & 5.87 & 0.492 \\
$\begin{array}{l}\text { I care more about the brand than the price and raw materials. } \\
\begin{array}{l}\text { I care more about uniqueness of clothes regardless less of whether } \\
\text { or not it is keeping up with modern fashion lines. }\end{array}\end{array}$ & $\mathbf{8 . 6 1}$ & 0.051 \\
\begin{tabular}{l} 
I look for clothes that compliment and go with what I already have. \\
\hline
\end{tabular} & 2.96 & 0.013 \\
\hline
\end{tabular}

trends more than students of other majors. Also, there were statistically significant differences attributable to the academic majors with regard to interest in brand more than in price and raw material $(P$-value $<0.05)$ as female students in other majors are less interested in brand name than female students of Textiles and Design major.

Meanwhile, there were no statistically significant differences attributable to the academic majors with regard to other variables including zooming in on model's image to see details of materials and accuracy and cleanliness of its knitting, interest in modern designs and price when choosing clothes more than in raw materials, uniqueness of clothing (regardless of whether or not it follows modern fashion lines), and finally finding clothing that complement and match what they already have.

Third hypothesis: There is a difference in the number of returned clothes between female students of other academic majors and students of Fashion and Textile major.

It is evident from Table 4 that there is a statistically significant difference in the number of returns of clothes between female students of other academic majors and students of Fashion and Textile major $(P$-value $<0.05)$, as female students of textiles and design were less likely to return and replace the clothes that they bought electronically compared to female students of other academic majors. There were no statistically significant differences attributable to academic majors with regard to other variables including interest in reviewing after-sales services (replacement, return) before purchasing, and facilitation of after-sales services on the site. 
Fourth Hypothesis: Students of Fashion and Textile major can determine the ideal choice for body style from among similar clothing designs.

It is evident from Table 5 that there is a statistically significant relationship between selection of ideal choice for body type from among similar designs for clothing, and academic major ( $P$-value $<0.05)$, as it easy for students of Textiles and Design major to choose clothes that fit the style of the body when seeing many designs that are similar in terms of (material, shape, sewing styles), while students of other majors sometimes face difficulty in that.

Fifth hypothesis: Students of Fashion and Textile major are distinguished in their ability to make adjustments to the clothes after purchasing it and add some aesthetic touches to increase its value of appearance.

It is evident from Table 6 that there is a statistically significant relationship between students' ability to make adjustments to the clothes after purchasing it and add some aesthetic touches to increase its appearance value, and their academic major $(P$-value $<0.05)$, as students of Textile and Design major have the ability to make adjustments to clothes after purchasing it and add some aesthetic

Table 4. The relation between the number of returned clothes between female students of other academic majors and female students of Fashion and Textile major.

\begin{tabular}{lcc}
\hline \multicolumn{1}{c}{ Study variable } & Chi-Square VALUE & $P$-value \\
\hline $\begin{array}{l}\text { Are you interested in viewing the after-sales services (replacement, } \\
\text { return) before purchasing? }\end{array}$ & 2.67 & 0.306 \\
$\begin{array}{l}\text { When the after-sales services are facilitated on site, this invites you } \\
\text { to buy faster. }\end{array}$ & 2.31 & 0.314 \\
$\begin{array}{l}\text { The number of returns and exchanges of clothes that you have } \\
\text { purchased online. }\end{array}$ & 9.55 & $\mathbf{0 . 0 0 8}$ \\
$\begin{array}{l}\text { If you don't return the clothes you bought, what do you do with } \\
\text { them? }\end{array}$ & 4.03 & 0.259 \\
\hline
\end{tabular}

Table 5. The relationship between the ability to determine the ideal choice for body style among similar clothing designs, and academic majors.

\begin{tabular}{lcc}
\hline \multicolumn{1}{c}{ Study variable } & Chi-Square VALUE & $P$-value \\
\hline $\begin{array}{l}\text { Is it easy for you to choose clothes that fit your body style when you } \\
\text { see many similar designs in terms of (material, shape? stitching } \\
\text { styles)? }\end{array}$ & 16.64 & 0.000 \\
\hline
\end{tabular}

Table 6. The relationship between students' ability to make adjustments to the clothes after purchasing it and add some aesthetic touches to increase its appearance value, and their respective academic major.

\begin{tabular}{lcc}
\hline \multicolumn{1}{c}{ Study variable } & Chi-Square VALUE & $P$-value \\
\hline I can buy one garment for multiple uses & 1.99 & 0.370 \\
I can make some adjustments to the clothes (after buying it online) & 3.05 & 0.218 \\
I can add some aesthetic touches to increase the appearance value. & $\mathbf{1 1 . 9 5}$ & $\mathbf{0 . 0 0 3}$ \\
\hline
\end{tabular}


touches to increase its appearance value more than female students of other academic majors. As for buying one clothing for several uses, and making some adjustments to the clothes (after buying it online), there were no statistically significant differences in terms of academic major.

\section{Conclusion}

This study has generally aimed to examine the effect of difference in students' academic majors on practice of e-shopping of clothes and showcase how the academic major can have a tangible effect on consumers' behavior. Five questions were raised with aim to answer the study's hypothesis. It was found that there are statistically significant differences at a significant level (0.05) between levels of practicing e-shopping of clothes among female students as per respective academic majors in favor of female students from Fashion and Textiles major. It was found that there are statistically significant differences at a significant level (0.05) between levels of practicing e-shopping of clothes among female students as per respective academic majors in favor of female students from $\mathrm{Fa}$ shion and Textiles major. The study has also revealed that there are statistically significant differences at a significant level (0.05) among female university students in terms of degree of interest in examining the raw materials of clothes and accuracy and cleanliness of knitted clothes, in favor of female students of Fashion and Textiles major. Additionally, the study has shown that the rate of returning clothes to stores is higher for female students of other academic majors compared to female students of Fashion and Textile major who rarely returned clothes after purchase. The results have also shown that female students of the Fashion and Textile major can determine the best choice for body style from among similar designs compared to female students of other academic majors. Finally, it was found that students of the Fashion and Textile major have the desire to make adjustments to the clothes after purchasing it, and add some aesthetic touches to increase its value of appearance compared to female students of other academic majors.

Thus, it is evident that academic majors can have an impact on consumers' behavior, and prior knowledge of fashion and design can be of significant benefits for consumers who like or would like to practice e-shopping of clothes. Informed consumers can enjoyably use e-shopping without concerns to endure burdens of clothes' returns or replacements, since they will already have the knowledge of type of raw materials and the other information related to displayed clothing items on the internet.

Therefore, the study recommends that there is a need to educate consumers on issues related to fashions and designs in order for them to practice e-shopping smoothly and easily.

\section{Conflicts of Interest}

The authors declare no conflicts of interest regarding the publication of this paper. 


\section{References}

Abdul-Ghani, A. (2005). The Internet's Role in Changing Marketing Strategies and Orienting Customers to the Electronic Market. Working Paper, Forum for Change Management and Development Requirements in Administrative Work, Saudi Management Association.

Al-Dabbagh, M. A. (2009). Clothing Marketing. Jeddah: Al Madinah Al Munawwarah Printing and Publishing Company.

Al-Khail, A., \& Saleh, T. B. (2020). Luxury Fashion Brands. Riyadh-Dubai-Beirut: Dar Madarak Publishing.

Anderson, J. C., \& Gerbing, D. W. (1988). Structural Equation Modeling in Practice: A Review and Recommended Two-Step Approach. Psychological Bulletin, 103, 411-423. https://doi.org/10.1037/0033-2909.103.3.411

Balasudarsun, N. L. (2017). Online Shopping Behavior of Students in Select Asian Countries (India, Malaysia, Singapore, Uzbekistan and Thailand). Journal of Contemporary Research in Management, 12, 97-99. https://search.proquest.com/docview/2070391930?accountid=43793

Farghali, Z. A. H. (2012). Women's Outerwear and Home Clothes. Cairo: Arab Thought House.

Ghalawat, S., Girdhar, A., Sangwan, A., \& Mehla, S. (2018). Factors Influencing Overall Satisfaction with the Services of Online Shopping among College Students. International Journal of Education and Management Studies, 8, 269-275.

https://search.proquest.com/docview/2159145488?accountid=43793

Kautish, P., \& Sharma, R. (2018). Consumer Values, Fashion Consciousness and Behavioural Intentions in the Online Fashion Retail Sector. International Journal of Retail \& Distribution Management, 46, 894-914. https://doi.org/10.1108/IJRDM-03-2018-0060

Kuswanto, H., Pratama, W. B. H., Ahmad, I. S., \& Salamah, M. (2019). Analysis of Students' Online Shopping Behaviour Using a Partial Least Squares Approach: Case Study of Indonesian Students. Cogent Business \& Management, 6, Article: 1699283. https://doi.org/10.1080/23311975.2019.1699283

Lee, J., \& Lee, Y. (2019). Does online Shopping Make Consumers Feel Better? Exploring Online Retail Therapy Effects on Consumers' Attitudes towards Online Shopping Malls. Asia Pacific Journal of Marketing and Logistics, 31, 464-479. https://doi.org/10.1108/APJML-06-2018-0210

Li, Y., \& Nakayama, T. (2019). Online Shopping Behavior in Case of Apparel Product: Comparative Analysis between Japanese and Chinese University Students. Revista De Management Comparat International, 20, 437-438, 440-449.

Ministry of Culture (2019). Report on the Cultural Situation in the Kingdom of Saudi Arabia 2019 AD. Riyadh: King Fahd National Library.

https://www.moc.gov.sa/ar/Media-center

Ofori, D., \& Appiah-Nimo, C. (2019). Determinants of Online Shopping among Tertiary Students in Ghana: An Extended Technology Acceptance Model. Cogent Business \& Management, 6, Article ID: 1644715. https://doi.org/10.1080/23311975.2019.1644715

Salem, I. K., \& Al-Masroumi, A. M. (2020). The Impact of Academic Specialization on Religious Values among Students of the Faculty of Knowledge. The University. Journal of the University's College of Knowledge, 30, 577-539.

https://uoajournal.com/index.php/maarif/article/view/162

Saudi Vision 2030. https://vision2030.gov.sa

Sethi, R. S., Kaur, J., \& Wadera, D. (2018). Purchase Intention Survey of Millennials to- 
wards Online Fashion Stores. Academy of Marketing Studies Journal, 22, 1-16. https://search.proquest.com/docview/2046107437?accountid=43793

Shaheen, S. A. M. (2007). The Effect of Academic Specialization and Cognitive Style on the Design and Production of the Electronic Achievement File Portfolio-E, among Student Teachers at the Faculty of Education, the Egyptian Association for Educational Technology. Educational Technology, 17, 1, 3.39.

Soleimani, K. A. G. (2018). 1+84 Practical Advice for Starting a Successful Entrepreneurial Project (6th ed.). Amman: Jabal Amman Publishers. 